\title{
PYROPES AND CHROMITES OF THE SNAP LAKE/KING LAKE KIMBERLITE DYKE SYSTEM IN RELATION TO THE PROBLEM OF THE SOUTHERN SLAVE CRATON LITHOSPHERIC MANTLE STRUCTURE AND COMPOSITION.
}

\author{
Nick Pokhilenko ${ }^{1,2}$, Bill Griffin ${ }^{3,4}$, N Shimizu $^{5}$, Cam McLean $^{1}$, Vladimir Malkovets ${ }^{2,3}$, \\ Lucy Pokhilenko ${ }^{2}$, Elena Malygina ${ }^{2}$ \\ ${ }^{1}$ Diamondex Resources Ltd., Canada; ${ }^{2}$ Institute of Mineralogy and Petrography, Russia; ${ }^{3}$ GEMOS Key Centre, Macquarie \\ University, Australia; ${ }^{4}$ CSIRO Exploration and Mining, Australia; ${ }^{5}$ Woods Hole Oceanographic Institution, USA.
}

\section{INTRODUCTION}

Previous petrological and mineralogical studies have demonstrated an increase of the Slave Craton lithosphere thickness from $160-180 \mathrm{~km}$ for its northern region (Kopylova et al., 1999) to a minimum of $230 \mathrm{~km}$ (Kennady Lake area, Kopylova et al., 2001) and even to $300 \mathrm{~km}$ (Snap Lake area, Pokhilenko et al., 2000, 2001) for the southern region. The Peculiarities of composition and distribution of crystalline inclusions in diamonds from the Snap Lake/King Lake (SL/KL) kimberlite dyke system suggest relatively less depleted peridotites predominate and the presence of abnormal thickness for the southern Slave Craton (Pokhilenko et al., 2001). An unusually wide range of $\mathrm{Cr}_{2} \mathrm{O}_{3}$ content (up to $16.1 \mathrm{wt} . \%$ ) exists in pyropes from the SL/KL kimberlites. This can be explained by the abnormal thickness and wide range of the lithospheric mantle peridotite compositions (Pokhilenko et al., 2000).

The presence of the very high Cr pyropes suggests that the garnetization reaction within depleted peridotites with the highest $\mathrm{Cr} /(\mathrm{Cr}+\mathrm{Al})$ values, had gone to completion (McLean et al., 2001).

Data obtained from the majorite-bearing high-Cr subcalcic pyrope inclusions in the SL/KL kimberlite diamonds suggest that moderately depleted Cr-pyrope harzburgites predominate in lithospheric mantle beneath the SL/KL area at depth $\sim 300 \mathrm{~km}$. There were no results suggesting a presence of significant melt related metasomatism even at this depth (Pokhilenko et al., 2001).

Garnets carry important information about composition, structure and types of metasomatic processes in the lithospheric mantle cross section (Griffin et al., 1995). Griffin et al. (1999) have studied the lithosphere structure and composition for the northern and central Slave Craton based on analysis of major element chemistry and geochemistry of the upper mantle xenoliths and Cr-pyropes from the kimberlites within the two regions. This data in the current study is related to the structure and composition of the lithospheric mantle beneath the SL/KL area, southern Slave Craton.

\section{METHODS}

Major element compositional variations of representative quantities of $\mathrm{Cr}$-pyrope ( $>2000$ grains) and chromite ( $>500$ grains) from the SL/KL dyke system kimberlites were studied using the CAMEBAX electron microprobes at Institute of Mineralogy and Petrography, Novosibirsk, University of Alberta, Edmonton, and School of Earth Sciences, Macquarie University, using standard techniques. Over $250 \mathrm{Cr}$ pyrope grains were analyzed for trace elements with a laser-ablation ICPMS microprobe at School of Earth Sciences, Macquarie University; the Ni, Ga, Y, and $\mathrm{Zr}$ contents for these grains were obtained by both LAMICPMS and the HIAF proton microprobe (PMP analyses were obtained at CSIRO Exploration and Mining, North Ride). For more than 450 previously EMP-analyzed pyrope grains, contents of $\mathrm{La}, \mathrm{Ce}, \mathrm{Nd}$, $\mathrm{Sm}, \mathrm{Eu}, \mathrm{Dy}, \mathrm{Er}, \mathrm{Yb}, \mathrm{Ti}, \mathrm{V}, \mathrm{Sr}, \mathrm{Y}$, and $\mathrm{Zr}$ were obtained using a CAMECA IMS $3 \mathrm{f}$ ion probe at Oceanographic Institution, Woods Hole.

\section{RESULTS}

Major element chemistry of Cr-pyropes and chromites from the SL/KL kimberlites was described in detail by N.P.Pokhilenko et al. (2000). New data shows the maximum $\mathrm{Cr}_{2} \mathrm{O}_{3}$ content in the $\mathrm{SL} / \mathrm{KL}$ kimberlite pyrope population has increased to $17.6 \mathrm{wt} \%$ (Fig. 1). The increased amount of data for Cr-pyrope grains supports the initial conclusions that there are a relatively low proportions of low-Ca high-Cr pyropes of dunite-harzburgite paragenesis $(\sim 4 \%)$, and of $\mathrm{Ca}-$ Cr-rich garnets of wehrlite paragenesis $(<2 \%$, Fig. 1$)$. Nearly $3.5 \%$ of the analyzed pyropes contain more than 
12 wt. $\% \mathrm{Cr}_{2} \mathrm{O}_{3}$, which makes them unique among the pyrope populations from all other kimberlites.

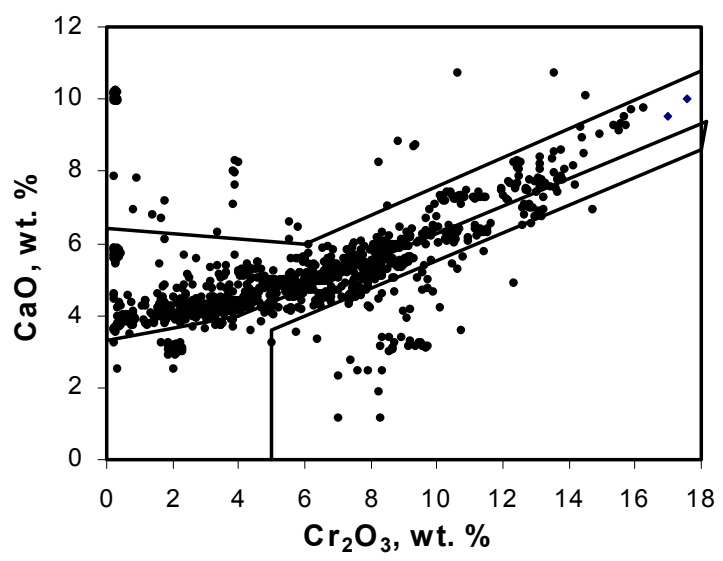

Figure 1: $\mathrm{Plot} \mathrm{CaO}$ vs $\mathrm{Cr}_{2} \mathrm{O}_{3}$ for the pyropes of the $\mathrm{SL} / \mathrm{KL}$ kimberlite.

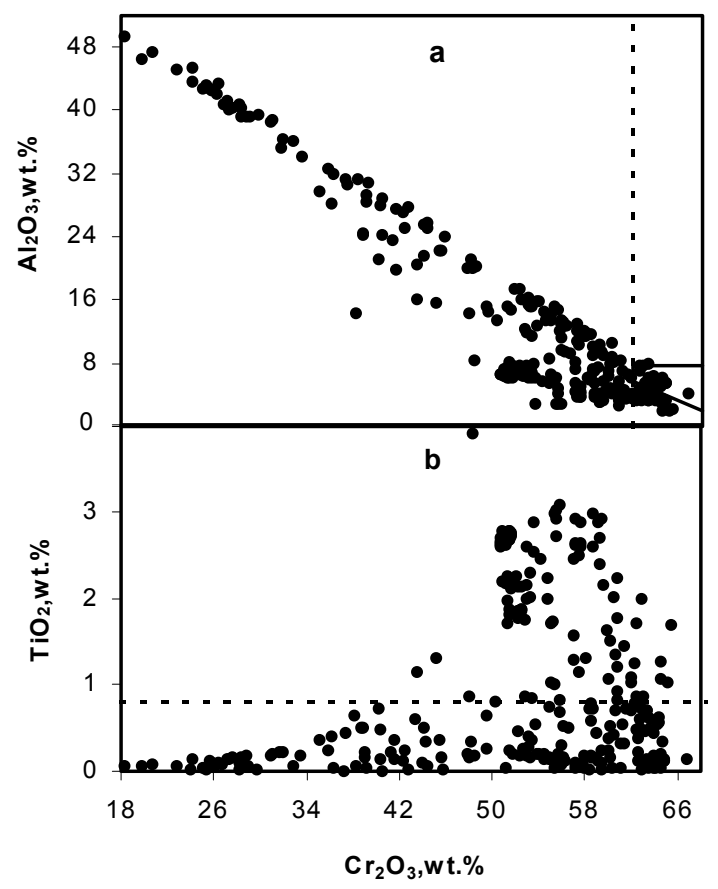

The most important features of the major element chemistry of the SL/KL chromites are: 1) very high proportion $(\sim 27 \%)$ of high-Cr $\left(>62\right.$ wt.\% $\left.\mathrm{Cr}_{2} \mathrm{O}_{3}\right)$ chromite with low $\mathrm{TiO}_{2}$ content $(<0.7$ wt.\%); 2) relatively low proportion of chromites enriched in both ulvospinel and hematite components (Fig. 2).

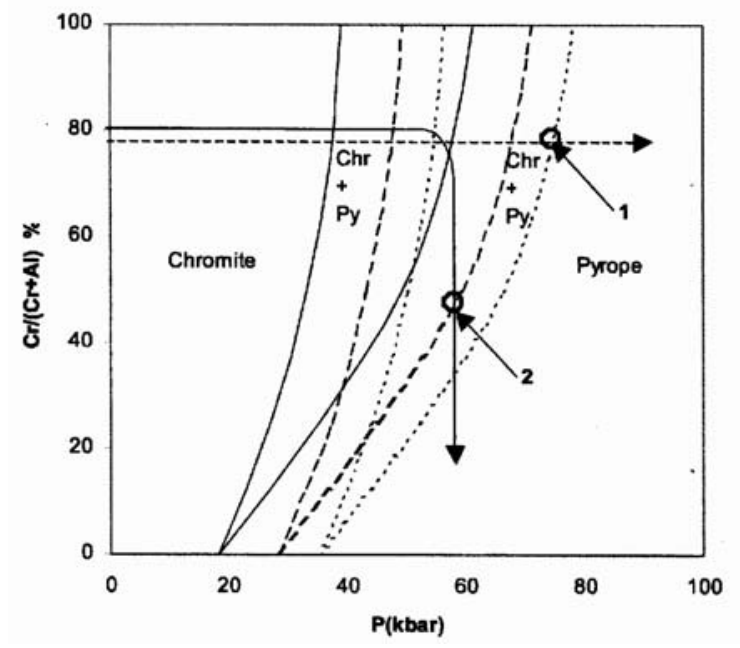

Figure 3: Scheme of reaction of garnetization $(\mathrm{En}+\mathrm{Chr} \leftrightarrow$ $\mathrm{Py}+\mathrm{Fo}$ ) for upper mantle peridotites (point of the reaction completion for the peridotites with maximum $\mathrm{Cr} /(\mathrm{Cr}+\mathrm{Al})$ ratio for lithospheric mantle of the Southern Slave Craton (1) and for the Siberian and Kaapvaal Cratons (2).

The presence of a significant proportion of extremely high-Cr pyropes together with the high proportion of high-Cr chromites in the SLK kimberlites is good evidence that the garnetization reaction of peridotites, with the highest $\mathrm{Cr} /(\mathrm{Cr}+\mathrm{Al})$ ratios $(>75 \%)$, had gone to completion (Fig. 3). This requires pressures of over 60 $\operatorname{kbar}(+200 \mathrm{~km})$, which in turn requires the existence of depleted peridotites (Cr-pyrope harzburgites) in the $\mathrm{SL} / \mathrm{KL}$ area lithospheric mantle at such depths.

The most interesting of the trace element results are: 1) $\sim 75 \%$ of pyropes of lherzolite paragenesis with $\mathrm{Cr}_{2} \mathrm{O}_{3}$ content $>12$ wt.\% demonstrate LREE-enriched and sinusoidal patterns which are characteristic for Cr-rich subcalcic pyrope inclusions in diamonds (Fig. 4). 2) The majority of lherzolitic pyropes with moderate to high $\mathrm{Cr}_{2} \mathrm{O}_{3}$ content (5-10 wt.\%), elevated $\mathrm{TiO}_{2}(>0.3$ wt.\%) and $\mathrm{FeO}(>8$ wt.\%) contents demonstrate smooth LREE-depleted patterns typical for mantle pyropes of lherzolitic paragenesis with [La] $\mathrm{n} \sim 0.1$ and $[\mathrm{Yb}] \mathrm{n} \sim 10$.

\section{CONCLUSIONS}

Analysis of the data leads to the following conclusions: 1. The most depleted peridotites were developed in the upper part of the SL/KL area lithospheric mantle down to depths of $\sim 150-160 \mathrm{~km}$. The interval between 160 and $210 \mathrm{~km}$ was represented by a mixture of depleted (Cr-pyrope harzburgites) and relatively undepleted (depleted Cr-pyrope lherzolites) peridotites as supported by distributions of $\mathrm{Zr}$ and $\mathrm{Ti}, \mathrm{Y}$ and $\mathrm{Ga}$ abundances and $\mathrm{Y} / \mathrm{Ga}-\mathrm{Zr} / \mathrm{Y}$ ratios. This is consistent with the proposal that most of the pyropes are related 
with depleted peridotites of the lithospheric mantle (Pokhilenko et al., 2000, 2001) and that some of them had equilibrated with relatively fertile lherzolites.

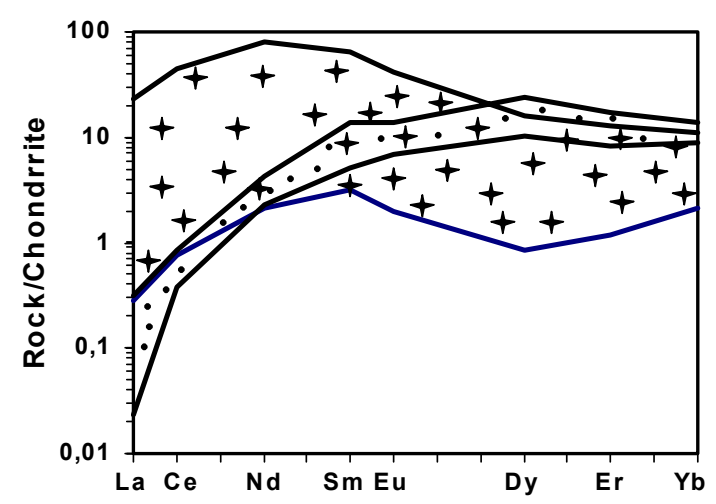

Figure 4: LREE patterns and fields of the extremely highCr pyropes $\left(\mathrm{Cr}_{2} \mathrm{O}_{3}>12\right.$ wt.\%, crosses $)$ and pyropes with moderate to high $\mathrm{Cr}_{2} \mathrm{O}_{3}$ content $(5-10 \mathrm{wt} . \%)$ and with elevated $\mathrm{TiO}_{2}(>0.3$ wt. $\%)$ and $\mathrm{FeO}(>8$ wt.\%) contents (dots).

2. A significant number of high-Cr pyropes $(\sim 50 \%$ of pyropes with $\mathrm{Cr}_{2} \mathrm{O}_{3}$ content greater than 10 wt.\%, and $\sim 75 \%$ with $\mathrm{Cr}_{2} \mathrm{O}_{3}>12$ wt.\%) have sinusoidal LREE patterns typical of subcalcic Cr-pyrope inclusions in diamonds. These pyropes have anomalously high $\mathrm{Sr}$ ( $>10 \mathrm{ppm}$ ), high $\mathrm{Sc} / \mathrm{Y}$ and high $\mathrm{Nd} / \mathrm{Y}$ ratios similar to those coexisting with diamonds. This data suggests that the SL/KL kimberlites have efficiently sampled a significant thickness of diamond-bearing lithospheric mantle.

Similar analytical data obtained for pyropes from kimberlites of the Lac de Gras area (Griffin et al., 1999) indicate that the deep lithosphere in this area $(\sim 200 \mathrm{~km})$ has experienced significantly higher melt-related metasomatism than the lithosphere sampled by SL/KL kimberlite and that this metasomatism markedly increases with depth. This, supports the possibility that a zone of intensive lithosphere-asthenosphere interaction underlies the Lac de Gras kimberlites at depth slightly deeper than $200 \mathrm{~km}$. The weak correlation between $\mathrm{Y}$ and $\mathrm{Ga}$ in pyropes obtained from the SL/KL kimberlite is typical of pyropes from moderate to strongly depleted peridotites. This suggests that there was very little melt-related metasomatism of the mantle Cr-pyrope peridotite suite sampled by $\mathrm{SL} / \mathrm{KL}$ kimberlites which points to a significantly deeper depth of the lithosphere-asthenosphere interaction zone than indicated for the Lac de Gras area.

\section{ACKNOWLEDGEMENTS}

We thank Winspear Resources Ltd. for providing of samples. This work was supported by Diamondex Resources Ltd. and by the Russian Foundation for Basic Research (Grant \# 01-05-65-166).

\section{REFERENCES}

Griffin, W.L., Kaminsky, F.V., O’Reilly, S.Y., Sobolev, N.V. (1995) Mapping the Siberian lithosphere with garnets and spinels. $6^{\text {th }}$ Int. Kimb. Conf. Ext. Abst., Novosibirsk, pp. 194-195.

Griffin, W.L., Doyle, B.J., Ryan, C.G., Pearson, N.J., O'Reilly, S. Y., Natapov, L., Kivi, K., Kretschmar, U., Ward, J. (1999) Lithospheric structure and mantle terranes: Slave Craton, Canada. Proc. $7^{\text {th }}$ Int. Kimb.Conf., J.B. Dawson Vol., Red Roof Design, Cape Town, pp. 299-306.

Kopylova, M.G., Russel, J.K., Cookenboo, H. (1999) Mapping the Lithosphere beneath the North Central Slave Craton. Proc. $7^{\text {th }}$ Int. Kimb. Conf., J.B. Dawson Vol., Red Roof Design, Cape Town, pp. 468-479.

McLean, R.C., Pokhilenko, N.P., Hall, A.E., Luth, R. (2001) Pyropes and chromites from kimberlites of the Snap Lake area, Southeast Slave Craton: garnetization reaction of depleted peridotites at extremely deep levels of the lithospheric mantle. Slave-Kaapvaal Workshop Ext. Abst., Merrickville, Ontario.

Pokhilenko, N.P., Sobolev, N.V., Tcherny, S.D., Mityukhin, S.I., Yanygin, Yu.T. (2000) Pyropes and chromites from kimberlites of Nakyn Field (Yakutia) and Snap Lake area (Slave Province, Canada): evidence of anomalous lithosphere structure. Doklady Akademii Nauk, 372(3), 356-360 (in Russian).

Pokhilenko, N.P., Sobolev, N.V., McDonald, J.A., Hall, A.E., Yefimova, E.S., Zedgenizov, D.A., Logviniva, A.M. (2001) Crystalline inclusions in diamonds from kimberlites of the Snap Lake area (Slave Craton, Canada): new evidence of anomalous lithosphere structure. Doklady Akademii Nauk, 380(3), 374-379 (in Russian).

Contact: RC McLean, 1410-650 West Georgia St. Vancouver, BC, Canada, V6B 4N8, E-mail: cmclean@diamondex.net 